\title{
Evaluation of Hyperbilirubinemia As A Diagnostic Marker for Acute Appendicitis
}

\author{
Madhu $\mathrm{Sn}^{1}$,Sreeramulu $\mathrm{Pn}^{1^{*}}$, Shashidar $\mathrm{Kn}^{2}$,Mohan Kumar $\mathrm{K}^{3}$,Bhaskaran $\mathrm{A}^{4}$, \\ Krishna Prasad $K^{5}$,Shashireka C A ${ }^{6}$,Srinivasand ${ }^{7}$, Naveed $^{8}$. \\ ${ }^{l}$ post Graduate, Dept Of General Surgery, ${ }^{1}$. Professor, \& Hod Dept. Of General Surgery \\ ${ }^{2}$ professor, \& Hod Dept. Of Biochemistry \\ ${ }_{3,4,5}$ Professor Dept. Of General Surgery \\ ${ }^{6,7,8}$ Assoc Professor Dept. Of General Surgery
}

\begin{abstract}
Background and Objectives: Acute Appendicitis is the commonest general surgical emergency, which needs early surgical intervention, to improve the outcome. The rate of misdiagnosis of appendicitis and the rate of appendicular perforation has remained constant, inspite of increased use of ultrasonography, computed tomography scanning and laparoscopy. For early and accurate preoperative diagnosis, acute appendicitis still remains an enigmatic challenge and is a reminder for the art of surgical diagnosis.

Our study was done to find if the Serum Bilirubin could be considered as a new laboratory marker to aid in the diagnosis of Acute appendicitis and if so, does it have the predictive capacity to warn us about Appendicular perforation.

Materials \& Methods: Patients reported to R L Jalappa Hospital and Research centre constituent, of Sri DevrajUrs Medical college, surgery department with acute abdomen, was considered for our study. The Study group included 100 patients. Maximum in the age group of 21-40 years. Clinically proven cases of acute appendicitis and perforation was considered. All the cases were evaluated biochemically to find if any association of serum bilirubin existed/present with clinically proven acute appendicitis.

Results: In our study, males were (51\%) and females (49\%) with overall mean age was $25.41 \pm 11.44$ years. Of the 100 patients, on HPR $82 \%$ were confirmed as acute appendicitis while $11 \%$ were diagnosed with Appendicular perforation and 7\% were diagnosed as recurrent appendicitis. Of 82 patients with acute appendicitis, $69.5 \%$ had elevated bilirubin levels, while $30.5 \%$ had normal levels. 11 patients were diagnosed as Appendicular perforation, all patients had elevated bilirubin levels. Of 7 patient with recurrent appendicitis $28.6 \%$ patient had elevated bilirubin levels, while $71.4 \%$ had normal levels. The Sensitivity and Specificity of serum bilirubin as a marker in predicting Acute appendicitis was $69.51 \%$ and $27.78 \%$ respectively. Similarly the Positive predictive value and Negative predictive value was $81.43 \%$ and $16.67 \%$ respectively with diagnostic accuracy was 62\%. ROC curve showing area under curve for acute appendicitis was 0.26 , and it was highest for appendicular perforation 0.98 with cut off bilirubin $1.85 \mathrm{mg} / \mathrm{dl}$ had $100 \%$ sensitivity and $92 \%$ specificity in diagnosis of appendicular perforation.

Conclusion: Serum bilirubin levels comes out to be a favorable laboratory marker for diagnosing acute appendicitis, however diagnosis of appendicitis remains static - clinical. Its level appears to be a useful marker in diagnosis of appendicitis and would be helpful in managing acute cases.

Patients with clinical signs and symptoms of appendicitis and with hyperbilirubinemia more than the normal range should be considered as having a higher chance of Appendicular perforation suggesting, serum bilirubin levels have a promising predictive potential for the early diagnosis of Appendicular perforation.
\end{abstract}

\section{Introduction}

Acute appendicitis is the most common cause of "Acute Surgical abdomen"1,2. Appendicectomy is the commonest emergency abdominal surgery, performed by a surgeon,Diagnosis of Appendicitis still remains a puzzle in spite of advances in the radiological and laboratory investigations. Diagnosis of appendicitis could be accurately made only with a combination of history, physical examination and laboratory studies, as per a clinician has experienced ${ }^{3}$. Although most patients with Acute Appendicitis can be easily diagnosed, a firm diagnosis still remains difficult as the sign and symptoms are variable in some cases. This is particularly true where the appendix is retrocaecal or retroileal. Following appendicectomies the percentage of appendix found to be normal varies $15-50 \%$ and postoperative complications can occur in up to $50 \%$ of these patients. ${ }^{4,5}$. Hence, a delay in diagnosis of Acute Appendicitis leads to perforation and peritonitis and increased mortality. Perforation ranges from 50-90\% in various cases. It is documented that clinical diagnosis is often biased and needs an adjuvant which shall substantiate the confirmation. This could prevent unnecessary surgical intervention. In such case, laboratory investigations such as White Blood Cell (WBC) counts and C-reactive 
protein (CRP) etc needs to be stressed upon. ${ }^{8}$ The use of Ultrasonography (USG) as a diagnostic tool for appendicitis has been well known.$^{9-12}$ To clinch an accurate diagnosis various scores combining clinical features and laboratory investigations have also been developed. These are the Alvarado score ${ }^{13}$ and the Modified Alvarado score. However till date there is no confirmatory laboratory marker for the pre-operative diagnosis of acute appendicitis and/ or appendicular perforation or recurrent appendicitis, moreover those which are done are neither clear nor conclusive.

Although, the significance of serum bilirubin was reported recently, the importance of the elevated total bilirubin has not been stressed in acute appendicitis and appendicular perforation. ${ }^{15}$ It is well established that when microbes invade the body, leukocytes defend it. This leads to increase in the leukocyte count and further leads to release of pro-inflammatory cytokines such as TNF-alpha, IL6 and other cytokine which occurs due to Bacterial invasion in the appendix and transmigration of bacteria. These inflammatory cytokines reach the liver via Superior mesenteric vein (SMV) and may produce inflammation, abscess or dysfunction of liver either directly or indirectly by altering the hepatic blood flow resulting in alteration of liver function tests particularly the bilirubin values.This created an interest in us to find any relationship between hyperbilirubinemia and acute appendicitis and to evaluate its credibility as a diagnostic marker for acute appendicitis and also, to find if any correlation level of elevated bilirubin levels do have a predictive potential role in the diagnosis of appendicular perforation.

\section{Objectives}

1. To estimate serum bilirubin in patients with acute appendicitis

2. To correlate serum bilirubin level in appendicitis, appendicular perforation and recurrent appendicitis.

3. To study the relationship between hyperbilirubinemia and acute appendicitis and to evaluate its usefulness as a diagnostic marker for acute appendicitis.

4. To evaluate whether elevated bilirubin levels have a predictive potential for the diagnosis of appendicular perforation.

\section{Liver Function Tests}

The significance of serum bilirubin was reported recently, the importance of the elevated total bilirubin has not been stressed in acute appendicitis and appendicular perforation.

It is hypothesized that an association exists between hyperbilirubinemia and acute appenditics and its complications such as appendicular perforation. ${ }^{27}$

\section{Bilirubin}

Bilirubin (a tetrapyrrole, formerly referred to as hematoidin) is the end product of the metabolic degradation of haem (prosthetic group of haemoglobin), myoglobin, the cytochrome P450's and various other haemo-proteins. ${ }^{27}$ The serum level of bilirubin represents the balance between production and excretion (destruction) of these breakdown products. Laboratory evaluation of serum bilirubin allows detection in two forms:

1. Indirect or Unconjugated bilirubin (i.e. before hepatic metabolism)

2. Direct or Conjugated (i.e. after hepatic metabolism) ${ }^{28}$

Since bilirubin is a most significant toxic waste product, hepatic handling is designed to eliminate it from the body via biliary tract. There are various steps involved in this process namely

I. Hepatocellular uptake

II. Intracellular binding,

III. Conjugation and

IV. Excretion. ${ }^{27}$

Modern analytical methods document that normal plasma contains virtually no bilirubin conjugate. The 10 to $20 \%$ of the bilirubin in normal plasma that gives rise to prompt (Diazo) reaction is an artifact of kinetic of the Van Den Berg reaction which along with various modifications is the method most commonly used to quantitate bilirubin in clinical laboratories. Indeed, when direct reacting fraction is less than $15 \%$ of total bilirubin at virtually any total bilirubin concentration, the bilirubin in the sample can be considered as essentially all unconjugated.

Conjugated bilirubin (mono- and di-glucronide) is excreted across canalicular plasma membrane by an ATP dependant transport process mediated by multi-drug resistant- associated-protein-2(Canalicular membrane protein). The excretion of conjugated bilirubin by the canalicular transport mechanism is highly sensitive to injury. Accordingly, in hepatocellular disease as well as with other cholestatic or mechanical obstruction to the bile duct, bilirubin conjugates within the hepatocytes that is prevented from taking their normal pathway into the 
canaliculi and down the bile duct and may reflux into blood stream, resulting in mixed or less often a truly conjugated hyperbilirubinemia.

Hyperbilirubinemia occurs either due to haemolytic, hepatocellular or cholestatic diseases. Cholestatic and hepatocellular hyperbilirubinemia are associated with a rise in liver enzymes. In these cases the bilirubin is predominantly direct in type (mixed type). An isolated serum bilirubin elevation (without enzyme elevation) may be familial or due to hemolysis.Cholestasis is the failure of normal bile to reach duodenum. This may be due to pathology anywhere between the hepatocyte and ampulla of Vater. Intrahepatic cholestasis includes those conditions where there is no demonstrable obstruction to major bile duct. The causes are drugs, hormones, primary biliary cirrhosis and sepsis. ${ }^{29}$ Sepsis reaches to the liver through portal veinfrom the gastrointestinal tract as one of the most common route of the various routes. Any inflammatory condition may cause transmigration/translocation of bacteria; its toxin or cytokines may cause suppression of hepatocellular function and reduced excretion of bile from biliary canaliculi. ${ }^{30}$

\section{Hyper biliru binemia And Appendicitis}

Hyperbilirubinemia, defined as an elevated level of serum bilirubin in the blood, either because of increased bilirubin production or alteration of bilirubin clearance. Serum bilirubin is not a well recognized significant laboratory marker for aiding preoperative diagnosis of acute appendicitis and appendicular perforation. Both mechanisms i.e increased production and alteration of bilirubin clearance, lead to an accumulation of bilirubin and might play a role in elevation of serum bilirubin in patients with appendicular perforation.

Bacterial infections leading to hepatic dysfunction may be due of abnormalities in bile acid formation and bile flow. This ultimately can result in hyperbilirubinemia, which is a well-known side effect in the setting of bacterial infection and especially in septic patients. ${ }^{59}$ Septic patients those with extrahepatic bacterial infection, such as in perforated appendicitis, show a proinflammatory cytokine and nitric oxide - triggered cholestasis by impairing hepatocellular and bile duct function.Further, Escherichia coli and Bacteroidesfragilis are the most common bacterial species cultured from appendicular wall of patients with acute appendicitis, both of which have been shown to interfere with hepatocytemicrocirculation, including sinusoidal damage as shown in a rat liver model. E. Coli associated lipopolysaccharides have been shown to have an effectonhepatocyte uptake and excretion of bile acids. ${ }^{35}$ Endotoxin secreted from $E$. Coli leads to a dose-dependent impairment of choleresis(production of bile from the liver), which has been shown in a rat model ${ }^{36}$ In addition, E. Coli infection has been shown to induce hemolysis of regular erythrocytes. ${ }^{37}$ This leads to an increased bilirubin load in infected individuals, which likely promotes hyperbilirubinemia. In Summarising the patho-physiology behind the elevation of Sr. Bilirubin in Acute Appendicitis/Appendicular perforation: ${ }^{15,26}$

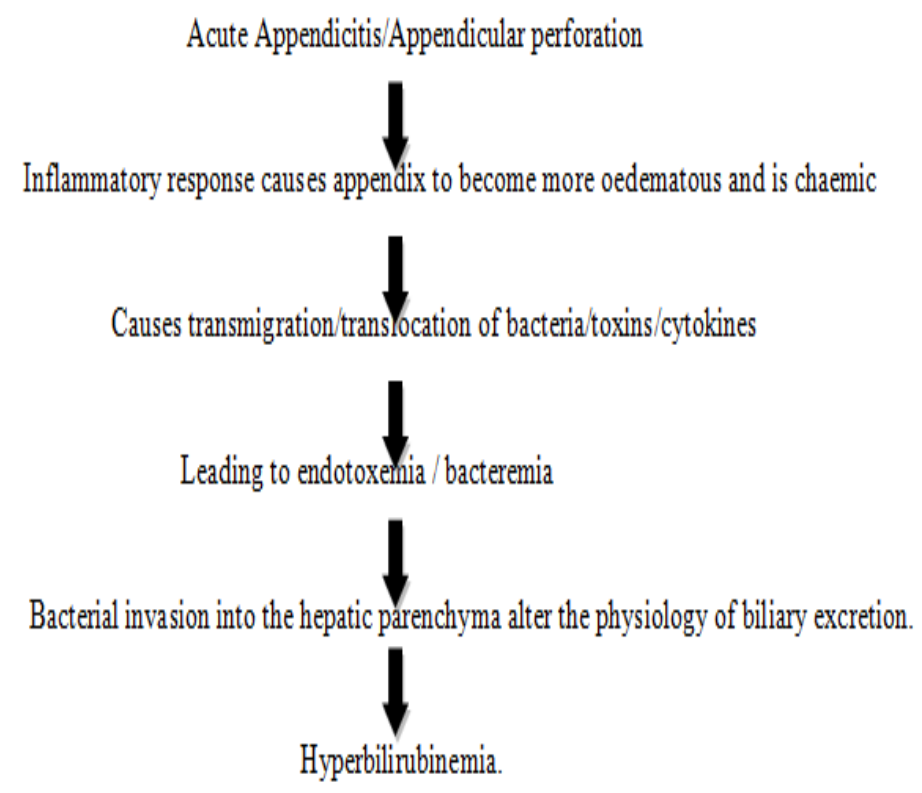

The mechanism of hepatic injury in sepsis could be because of bacteria, its toxin or cytokines. In early sepsis bacteria and its toxin or cytokines are involved, where as in late sepsis, ischemia is common mechanism of hepatic injury due to decreased hepatic blood flow. In both above situations the hepatic injury leads to 
dysfunction of hepatocyte and tubule leading to mixed type of hyperbilirubinemia (hepatocellular and intra hepatic cholestasis).

Cholestasis in chronic bacterial infection, particularly in childhood or post operatively, is presumably hepatocellular in nature. It can be due to cholestatic effect of endotoxin on sodium-potassium-ATPase. All the constituents of bile show an increased level in serum. Conjugation of biliary substance is intact but excretion is defective. Serum alkaline phosphatase is raised. The rise is due to increased synthesis or release of enzymes from liver or biliary plasma membrane. The minimal elevation in transaminase value and sometimes serum bilirubin, are the markers for hepatocellular damage A few case reports describe hyperbilirubinemia and jaundice as a clinical observation in patients with appendicitis. ${ }^{39,40}$ However there is a lack of studies with a larger group of patients.

It is inconclusive evidence that an association exists between hyperbilirubinemia and acute appendicitis and its complications. ${ }^{26}$ There are only a few case reports in the available literature that describe the finding of hyperbilirubinemia in patients of acute appendicitis. ${ }^{26}$

\section{Materials And Methods}

Patients reported to R L Jalappa Hospital and Research centre constituent of sriDevrajUrs Medical college, surgery department with acute abdomen, was considered for our study. The Study group included 100 patients. Maximum in the age group of 21-40 years.Clinically proven cases of acute appendicitis and perforation was considered. All the cases were evaluated biochemically to find if any association of serum bilirubin with clinically proven acute appendicitis.

\section{Study design}

Prospective study.

Study place

Our study was conducted in the Department of Surgery, in R.L. JALAPPA HOSPITAL TAMAKA .

Study period

December 2014 to 2016.

Source of data

Patients admitted with clinical diagnosis of acute appendicitis or appendicular perforation or recurrent appendicitis under the Department of Surgery, in R.L. JALAPPA HOSPITAL TAMAKA during the study period.

\section{Sample size}

A total of 100 patients with clinical diagnosis of acute appendicitis or appendicular perforationor recurrent appendicitis were studied.

\section{Sampling method}

Sample size $=100$ was estimated based on the mean bilirubin level of $1.5+/-0.65$ in a study.

Alpha error at $1 \%$, power at $99 \%$

$\mathrm{n}=92$ expecting $10 \%$ of non response $\mathrm{n}=100$

\section{Selection criteria}

Inclusion criteria.

- All patients diagnosed as acute appendicitis clinically on admission.

- All patients diagnosed as appendicular perforation clinically on admission.

- All patients diagnosed as recurrent appendicitis clinically on admission.

For these groups, only patients with histopathological report suggestive of acute appendicitis or appendicular perforation or recurrent appendicitis were included.

\section{Exclusion criteria.}

- All patients documented to have a past history of

- Jaundice or Liver disease.

- Chronic alcoholism (that is intake of alcohol of $>40 \mathrm{~g} /$ day for Men and $>20 \mathrm{~g} / \mathrm{day}$ in Women for 10 years). ${ }^{71}$

- Hemolytic disease.

- Congenital or Acquired biliary disease.

- All patients with positive HBsAg.

- All patients with cholelithiasis.

- All patients with hepato-biliary system malignancy. 
- $\quad$ Procedure

- Ethical clearance has been obtained from "Ethical Clearance Committee" of the institution for the study. It is in the form of signature from Head of Dept. Surgery and Dean of SDUMC, TAMAKA ,KOLAR. Based on the selection criteria patients admitted with clinical diagnosis of acute appendicitis or appendicular perforation under Department of Surgery in R.L. JALAPPA HOSPITAL TAMAKA during the study period were screened for eligibility. The eligible patients were briefed about the nature of the study and a written informed consent (Annexure I) was obtained from the consented patients. Thorough history was taken and clinical examination was done for all patients and findings were recorded on predesigned and pretested proforma (Annexure II)

\section{The following tests were carried out on admission.}

- $\quad$ Routine blood investigations (Complete blood count, platelet count, reticulocyte count).

- Peripheral smear to rule out hemolyticanemia.

- Serum haptoglobulin if peripheral smear and blood tests indicate features of hemolyticanemia.

- Serum Bilirubin (Total and Direct bilirubin).

- $\quad$ Liver Function Tests (LFTs) which include;

o SGPT (Alanine transaminase).

o SGOT (Aspartate transaminase).

o ALP (Alkaline phosphatase).

- Seropositivity for HbsAg

- Urine analysis (routine and microscopy).

The serum bilirubin and LFTs were carried out using the Auto Analyser (cobas c 111) machine available in the hospital and HbsAg was tested by ELISA / Spot technique using HEPALISA ${ }^{\odot}$ or HEPACARD $^{\odot}$ kit.

\begin{tabular}{|c|c|}
\hline Test & Normal Range \\
\hline $\begin{array}{l}\text { Serum Bilirubin } \\
\text { Total } \\
\text { Direct }\end{array}$ & $\begin{array}{l}0.3-1.2 \mathrm{mg} / \mathrm{dl} \\
0.4-0.6 \mathrm{mg} / \mathrm{dl}\end{array}$ \\
\hline \begin{tabular}{|l} 
Liver Enzymes \\
SGOT \\
SGPT \\
ALP \\
\end{tabular} & $\begin{array}{l}-40 \mathrm{U} / \mathrm{L} \\
-35 \mathrm{U} / \mathrm{L} \\
-290 \mathrm{U} / \mathrm{L} \\
\end{array}$ \\
\hline
\end{tabular}

The results were grouped as „Normal" or „Raised" (hyperbilirubinemia) as per the above reference values

\section{Statistical analysis:}

Data was entered into Microsoft excel data sheet and was analyzed using SPSS 22 version software. Categorical data was represented in the form of Frequencies and proportions. Chi-square was used as test of significance. Continuous data was represented as mean and standard deviation. $p$ value $<0.05$ was considered as statistically significant.

\section{Screening of Disease:}

\begin{tabular}{|l|l|l|l|}
\hline \multirow{2}{*}{ Screening test results } & Diagnosis & \multirow{2}{*}{ Total } \\
\cline { 2 - 3 } & Diseased & Healthy & \\
\hline Positive & a (True postive) & b (False Postive) & a $+\mathrm{b}$ \\
\hline Negative & $\mathrm{c}$ (False Negative) & d (True Negative) & $\mathrm{c}+\mathrm{d}$ \\
\hline Total & $\mathrm{a}+\mathrm{c}$ & $\mathrm{b}+\mathrm{d}$ & $\mathrm{a}+\mathrm{b}+\mathrm{c}+\mathrm{d}$ \\
\hline
\end{tabular}

- $\quad$ Sensitivity $=a /(a+c) \times 100=$ True positive $/$ True positive + False Negative

- $\quad$ Specificity $=\mathrm{d} /(\mathrm{b}+\mathrm{d}) \times 100=$ True Negative $/$ True Negative + False Postive

- Positive predictive value $=\mathrm{a} /(\mathrm{a}+\mathrm{b}) \times 100=$ True Postive $/$ True positive + False Postive

- Negative predictive value $=d /(c+d) \times 100=$ True Negative $/$ True Negative + False Negative Diagnostic accuracy $=a+d / a+b+c+d=$ True postive + True Negative $/$ Total 


\section{Results}

Table 1: Gender distribution of subjects

\begin{tabular}{|l|l|l|l|}
\hline \multicolumn{2}{|c|}{} & Count & \% \\
\hline \multirow{3}{*}{ Gender } & Female & 49 & $49.0 \%$ \\
\cline { 2 - 4 } & Male & 51 & $51.0 \%$ \\
\cline { 2 - 4 } & Total & 100 & $100.0 \%$ \\
\hline
\end{tabular}

In the study majority of subjects i.e. $51 \%$ were males and $49 \%$ were females.

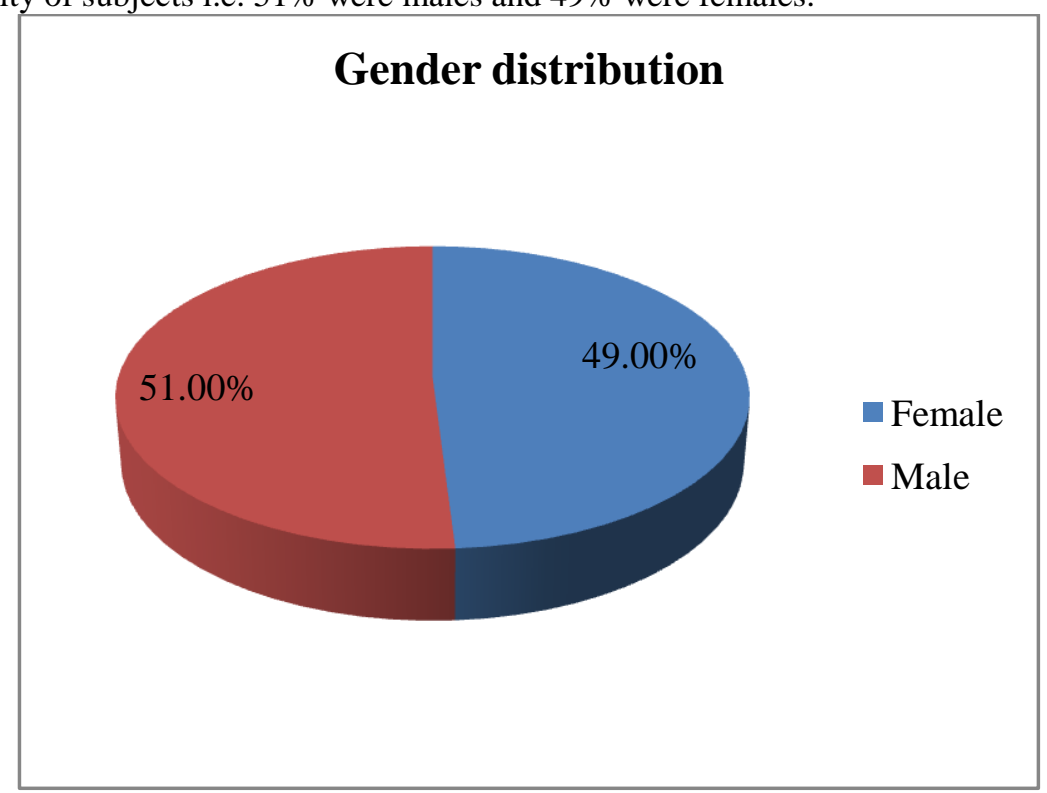

Figure 1: Pie diagram showing Gender distribution of subjects

Table 2: Age distribution of subjects with appendicitis

In the study $90 \%$ of subjects were below 40 years and $10 \%$ of them were above 40 years of age. Mean age of subjects was $25.41 \pm 11.14$ years.

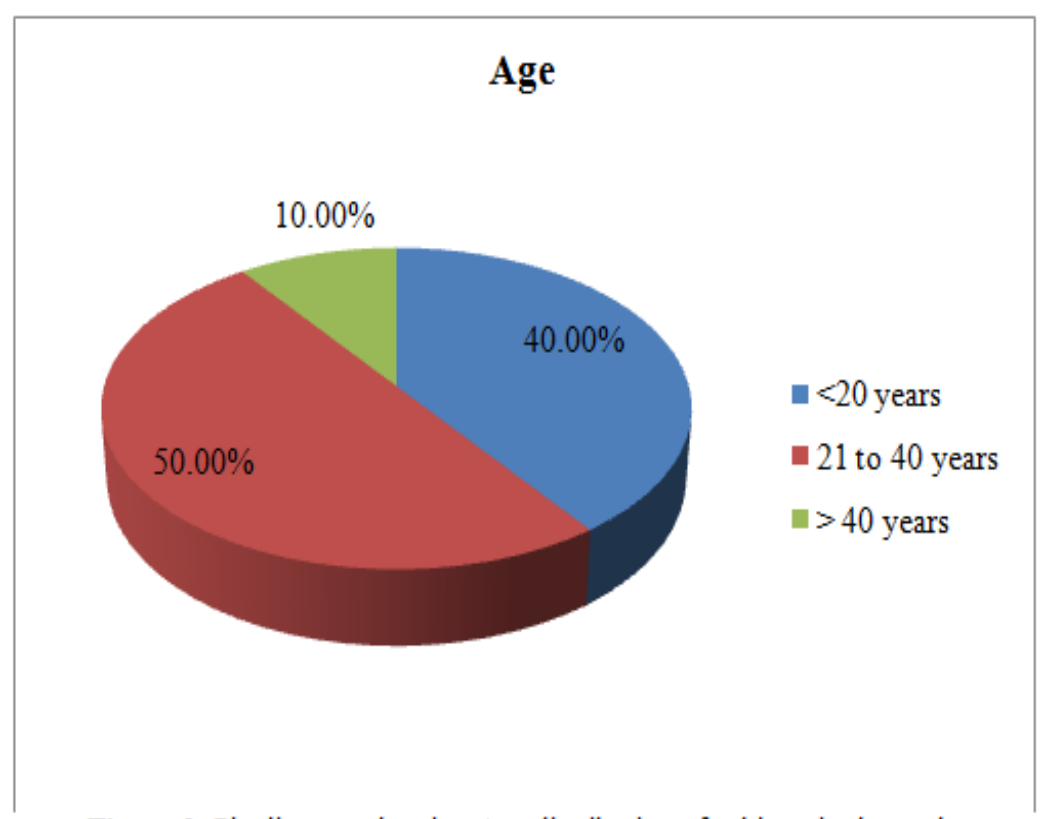

Figure 2: Pie diagram showing Age distribution of subjects in the study 
Table 3: Distribution of Liver function parameters and Total Leukocyte count in subjects

\begin{tabular}{|l|l|l|}
\hline & Mean & Standard Deviation \\
\hline Total Bilirubin & 1.3 & 0.6 \\
\hline Direct Bilirubin & 0.5 & 0.3 \\
\hline SGOT & 36.2 & 15.8 \\
\hline SGPT & 32.0 & 12.7 \\
\hline ALP & 164.6 & 97.6 \\
\hline TLC & 10.8 & 4.2 \\
\hline
\end{tabular}

Mean Total Bilirubin in subjects was $1.3 \pm 0.6 \mathrm{mg} / \mathrm{dl}$, Direct Bilirubin was $0.5 \pm 0.3 \mathrm{mg} / \mathrm{dl}$, SGOT was $36.2 \pm$ 15.8, SGPT was $32 \pm 12.7$, ALP was $164.6 \pm 97.6$ and TLC was $10.8 \pm 4.2$.

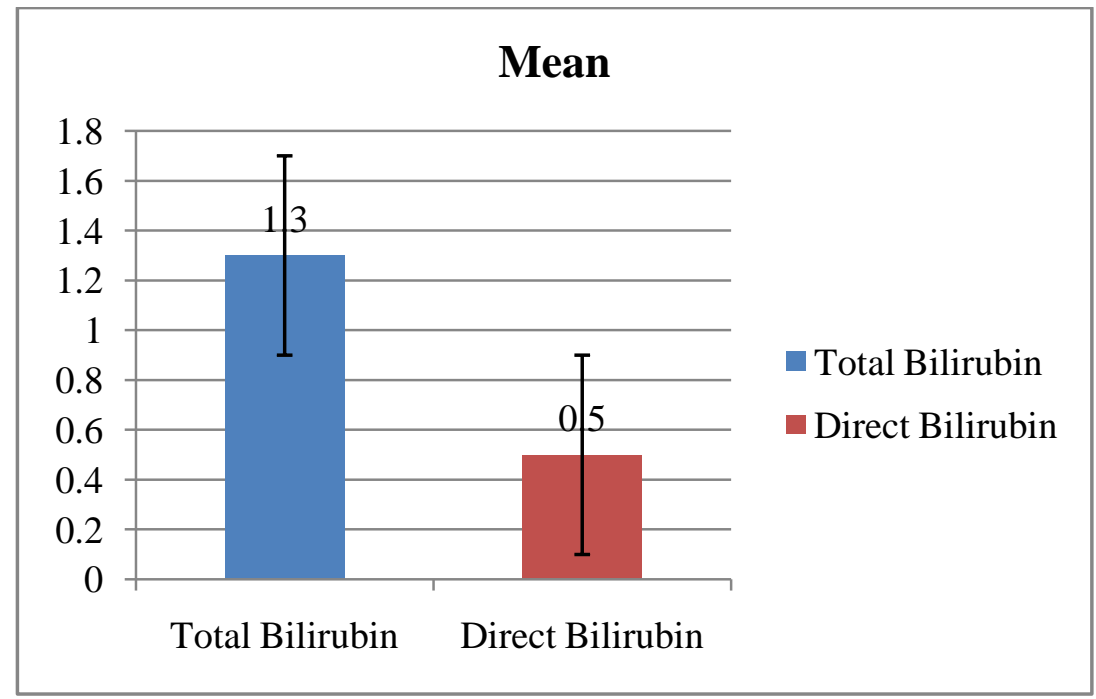

Figure 2: Bar diagram showing Mean Bilirubin levels

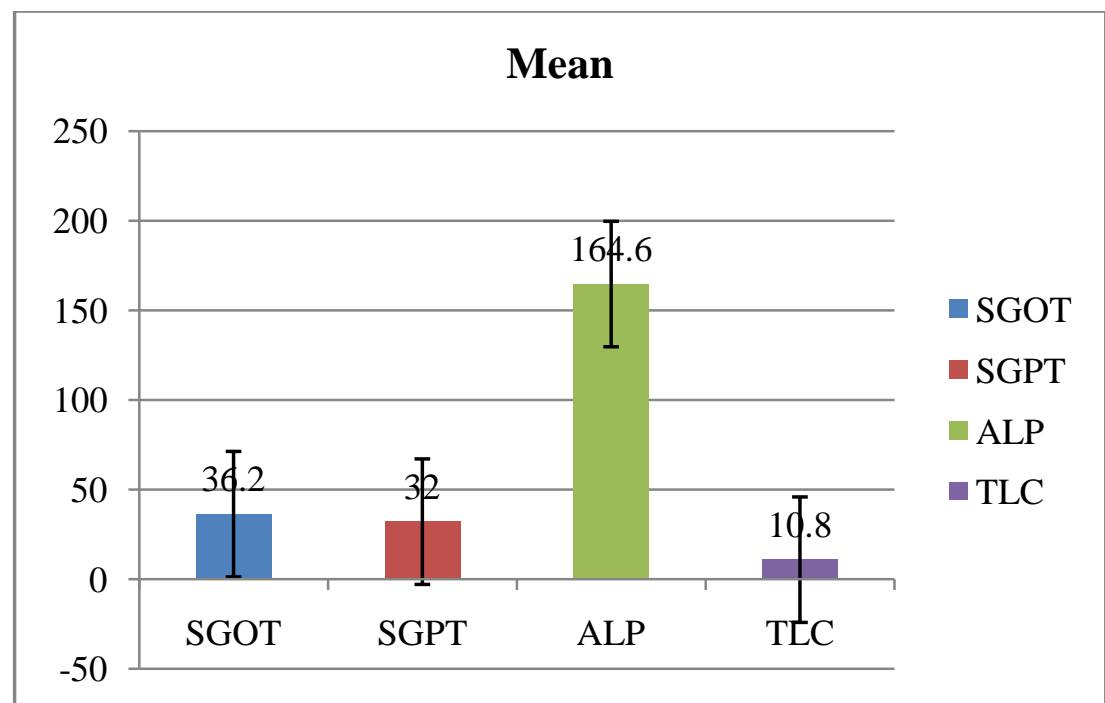

Figure 3: Bar diagram showing Liver function parameters and Total Leukocyte count

Table:4 Mean Total Bilirubin and Direct Bilirubin in Acute appendicitis and Appendicular perforation

\begin{tabular}{|c|l|l|l|l|}
\hline & \multicolumn{2}{|l|}{ Acute Appendicitis } & \multicolumn{2}{l|}{ Appendicular Perforation } \\
\cline { 2 - 5 } & Mean & SD & Mean & SD \\
\hline Total Bilirubin & 1.2 & 0.5 & 2.2 & 0.3 \\
\hline Direct Bilirubin & 0.4 & 0.3 & 0.9 & 0.4 \\
\hline
\end{tabular}

The mean bilirubin levels in patients diagnosed with Acute appendicitis was $1.2 \pm 0.5 \mathrm{mg} / \mathrm{dl}$, while in patients diagnosed with Appendicular perforation was $2.2 \pm 0.3 \mathrm{mg} / \mathrm{dL}$ 


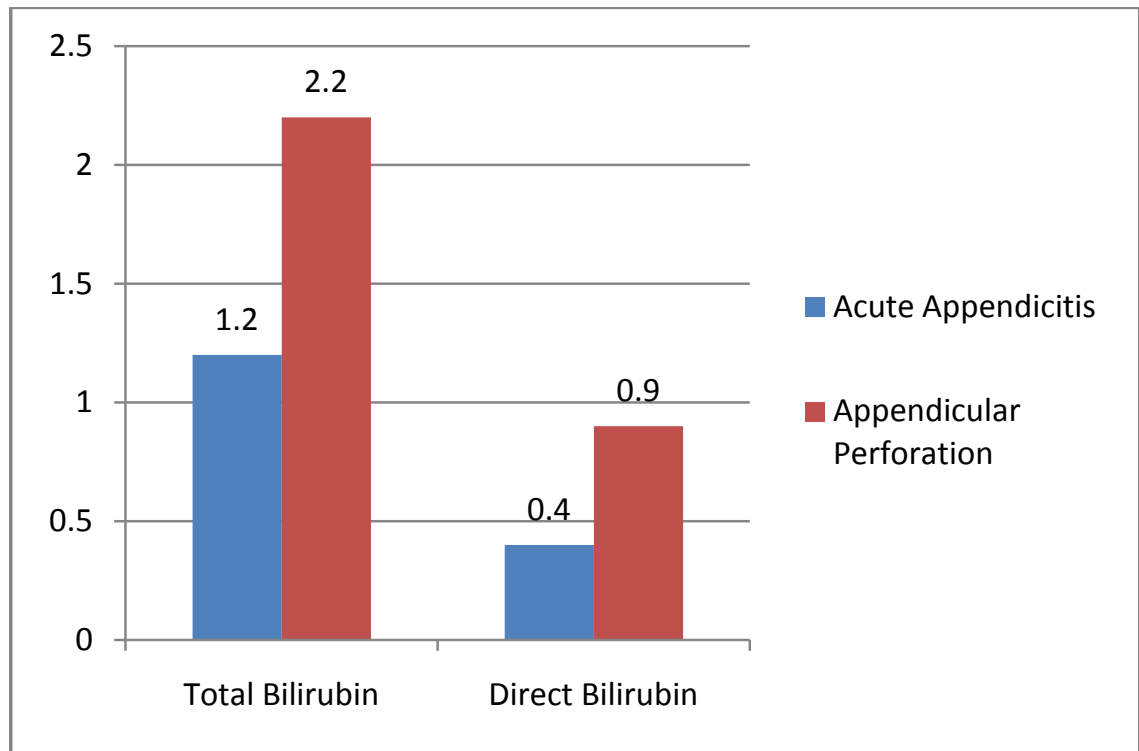

Figure 5: Bar diagram showing Mean Total Bilirubin and Direct Bilirubin in Acute appendicitis and Appendicular perforation.

Table 5: Diagnosis in subjects at different period and methods

\begin{tabular}{|l|l|l|l|}
\hline \multicolumn{2}{|c|}{} & Count & $\%$ \\
\hline \multirow{3}{*}{ Clinical Diagnosis } & AA & 87 & $87.0 \%$ \\
\cline { 2 - 4 } & AP & 5 & $5.0 \%$ \\
\cline { 2 - 4 } & RA & 8 & $8.0 \%$ \\
\hline \multirow{3}{*}{ Per operative Diagnosis } & AA & 86 & $86.0 \%$ \\
\cline { 2 - 4 } & AP & 11 & $11.0 \%$ \\
\cline { 2 - 4 } & RA & 3 & $3.0 \%$ \\
\hline \multirow{3}{*}{ HPR } & AA & 82 & $82.0 \%$ \\
\cline { 2 - 4 } & AGA\&P & 11 & $11.0 \%$ \\
\cline { 2 - 4 } & RA & 7 & $7.0 \%$ \\
\hline
\end{tabular}

In the study clinically $87 \%$ were diagnosed to have acute appendicitis, $5 \%$ as appendicular perforation and $8 \%$ as recurrent appendicitis. Per operatively $86 \%$ were diagnosed as acute appendicitis, $11 \%$ as appendicular perforation and $3 \%$ as recurrent appendicitis. Histopathologically $82 \%$ were diagnosed as acute appendicitis, $11 \%$ as appendicular perforation with gangrene and $7 \%$ as recurrent appendicitis.

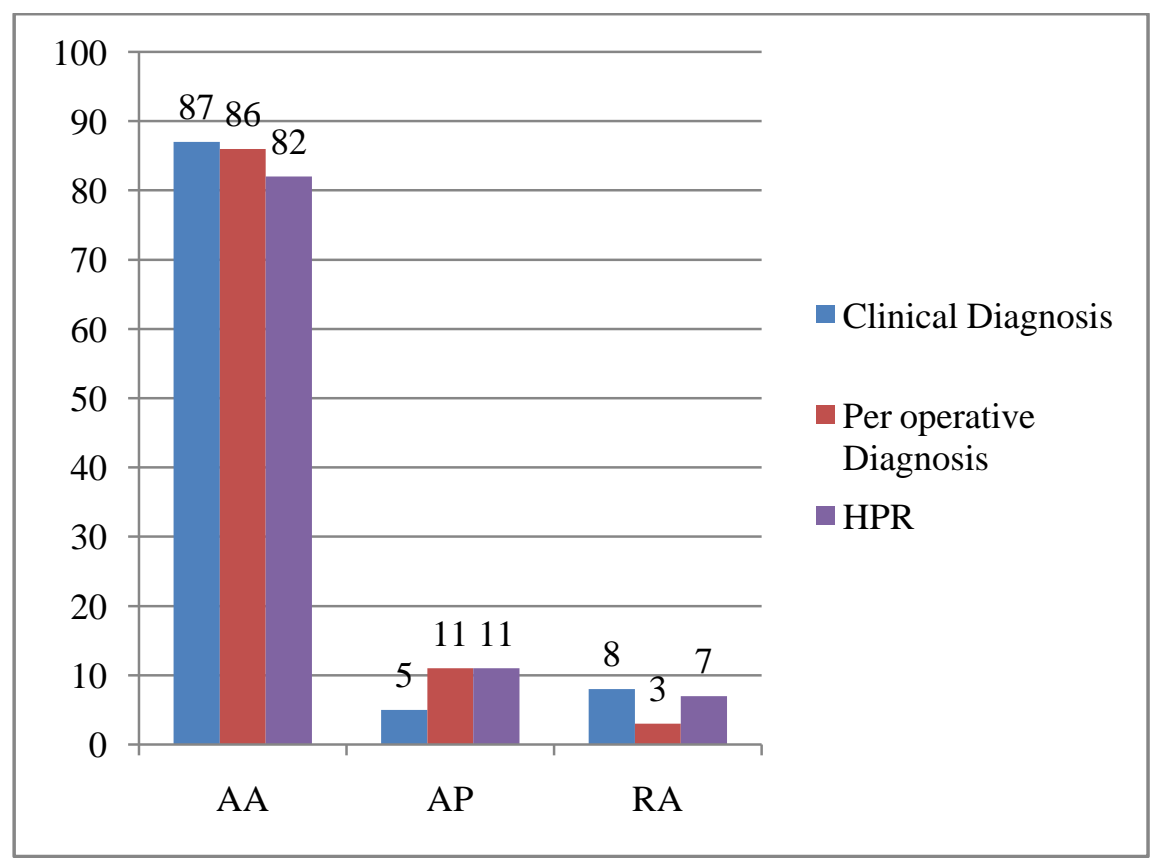

Figure 6: Bar diagram showing Diagnosis in subjects at various periods 
Table 6: Bilirubin levels and Hyperbilirubinemia in subjects

\begin{tabular}{|l|l|l|l|}
\hline \multicolumn{2}{|c|}{} & Count & $\%$ \\
\hline \multirow{2}{*}{ Total Bilirubin } & Normal & 37 & $37.0 \%$ \\
\cline { 2 - 4 } & Raised & 63 & $63.0 \%$ \\
\hline \multirow{2}{*}{ Direct Bilirubin } & Normal & 76 & $76.0 \%$ \\
\cline { 2 - 4 } & Raised & 24 & $24.0 \%$ \\
\hline \multirow{2}{*}{ Hyperbilirubinemia } & Absent & 30 & $30.0 \%$ \\
\cline { 2 - 4 } & Present & 70 & $70.0 \%$ \\
\hline
\end{tabular}

In the study Total Bilirubin was raised in $63 \%$ of subjects, Direct Bilirubin levels were raised in $24 \%$ and Hyperbilirubinemia was present in $70 \%$ of subjects based on raised total Bilirubin or raised direct Bilirubin.

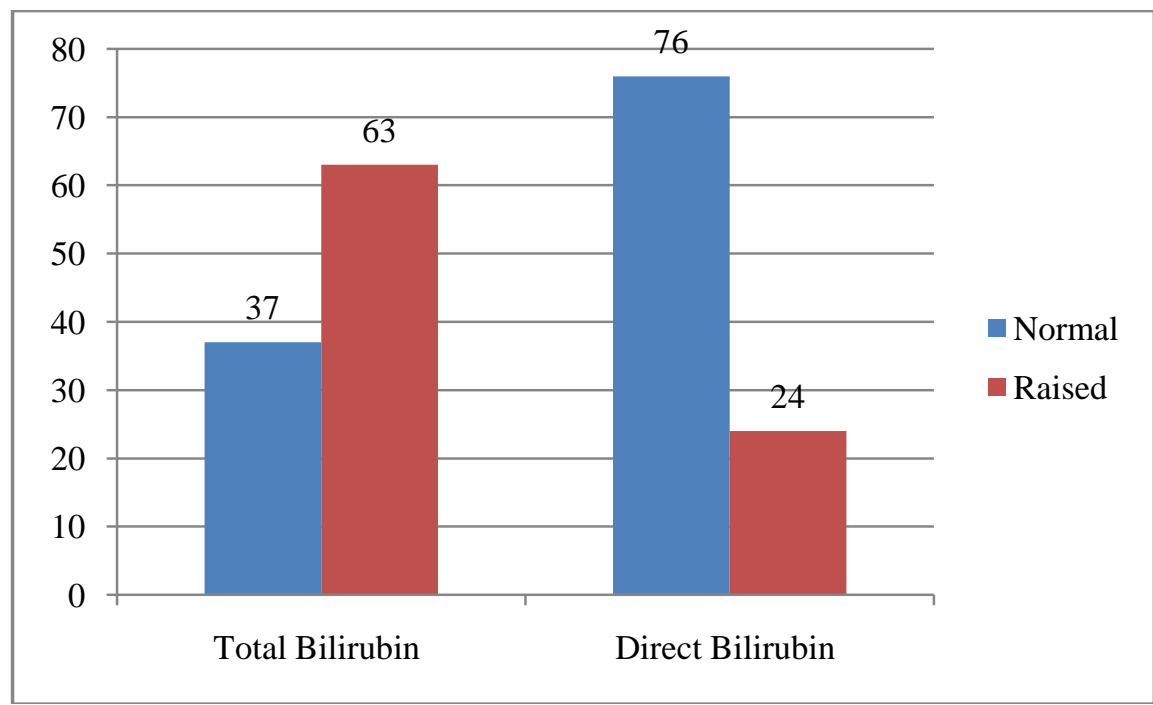

Figure 7: Bar diagram showing Bilirubin levels in subjects

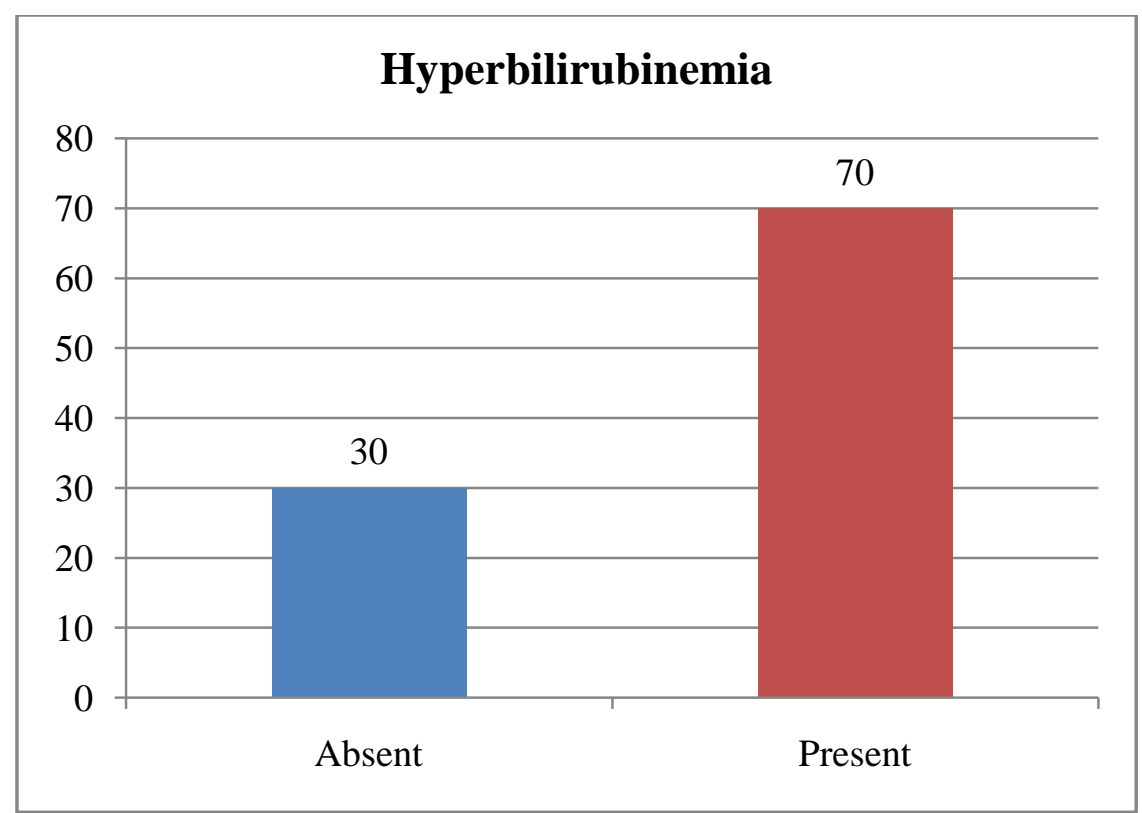

Figure 8: Bar diagram showing Bilirubin levels in subjects

Table 7: Association between Hyperbilirubinemia and clinical diagnosis

\begin{tabular}{|l|l|l|l|l|l|l|l|}
\hline \multicolumn{2}{|c|}{} & \multicolumn{5}{l|}{ Clinical Diagnosis } \\
\cline { 3 - 8 } \multicolumn{2}{|c|}{} & \multicolumn{2}{|l|}{ Acute Appendicitis } & Appendicular Perforation & \multicolumn{2}{l|}{ Recurrent Appendicitis } \\
\cline { 3 - 8 } & Count & $\%$ & Count & $\%$ & Count & $\%$ \\
\hline \multirow{2}{*}{ Hyperbilirubinemia } & Present & 63 & $72.4 \%$ & 5 & $100.0 \%$ & 2 & $25.0 \%$ \\
\cline { 2 - 8 } & Absent & 24 & $27.6 \%$ & 0 & $0.0 \%$ & 6 & $75.0 \%$ \\
\hline
\end{tabular}

$\mathrm{X}^{2}=10.099, \mathrm{df}=2, \mathrm{p}=0.006^{*}$ 
Out of 87 subjects who were clinically diagnosed as acute appendicitis $72 \%$ had Hyperbilirubinemia, out of 5 subjects who were clinically diagnosed as Appendicular Perforation $100 \%$ had Hyperbilirubinemia and $25 \%$ with recurrent appendicitis had Hyperbilirubinemia.There was significant association between Hyper biliru binemia and clinical diagnosis.

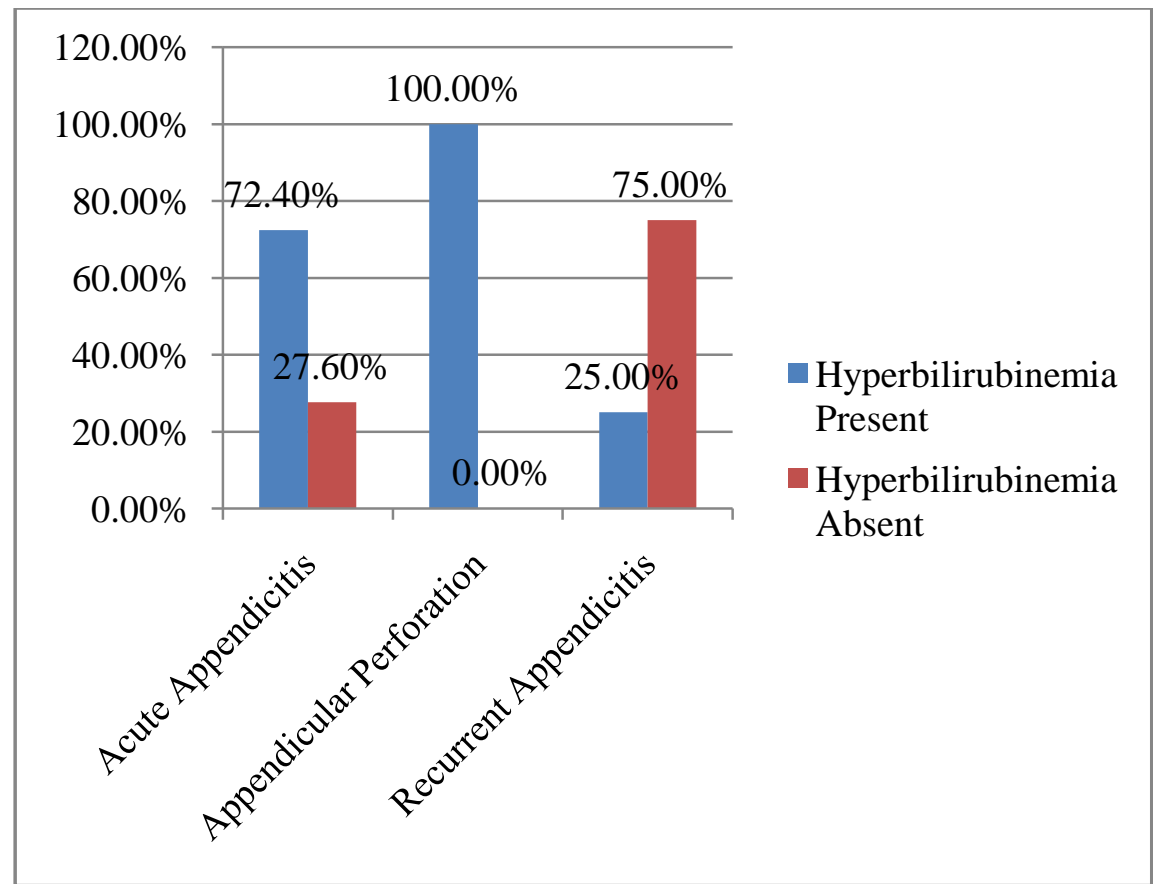

Figure 9: Bar diagram showing Association between Hyperbilirubinemia and clinical diagnosis

Table 8: Association between Hyperbilirubinemia and per operative Diagnosis

\begin{tabular}{|c|c|c|c|c|c|c|c|}
\hline & \multicolumn{6}{|c|}{ Per operative Diagnosis } \\
\hline & & \multicolumn{2}{|c|}{ Acute Appendicitis } & \multicolumn{2}{|c|}{ Appendicular Perforation } & \multicolumn{2}{|c|}{ Recurrent Appendicitis } \\
\hline & & Count & $\%$ & Count & $\%$ & Count & $\%$ \\
\hline \multirow{2}{*}{ Hyperbilirubinemia } & Present & 58 & $67.4 \%$ & 11 & $100.0 \%$ & 1 & $33.3 \%$ \\
\hline & \begin{tabular}{|l|} 
Absent \\
\end{tabular} & 28 & $32.6 \%$ & 0 & $0.0 \%$ & 2 & $66.7 \%$ \\
\hline
\end{tabular}

Out of 86 subjects who were diagnosed as acute appendicitis per operatively $67.4 \%$ had Hyperbilirubinemia, out of 11 subjects who were per operatively diagnosed as Appendicular Perforation 100\% had Hyperbilirubinemia and 33.3\% with recurrent appendicitis had Hyperbilirubinemia. There was significant association between Hyperbilirubinemia and per operative diagnosis.

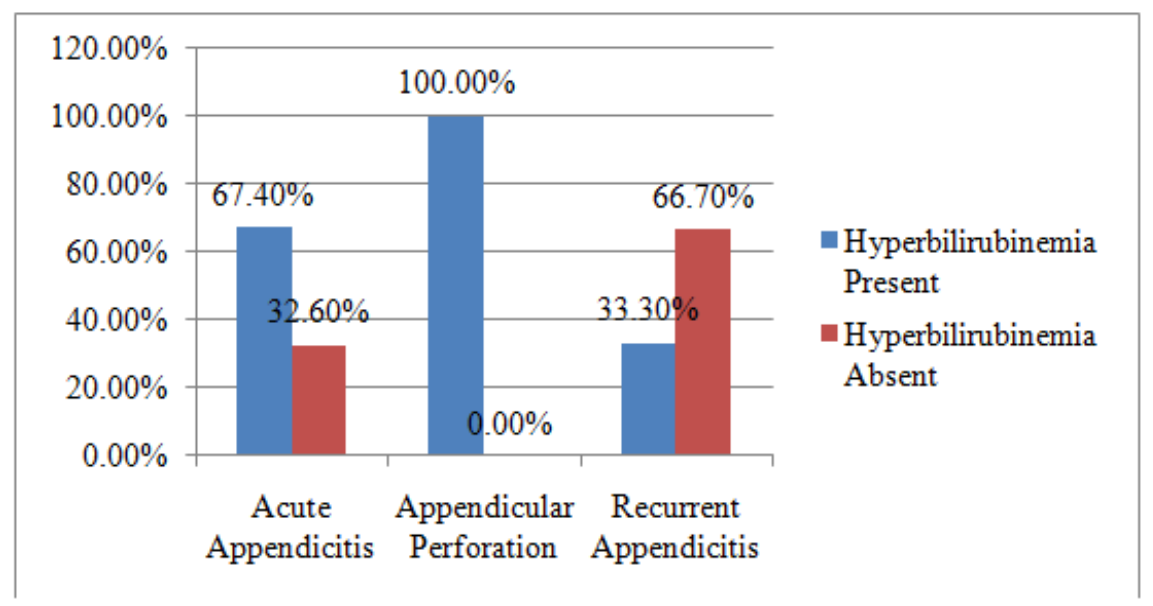

Figure10: Bar diagram showing Association between Hyper biliru binemia and pre operative diagnosis

Table 9: Association between Hyper bilirubinemia and Histopathological Diagnosis 


\begin{tabular}{|l|l|l|l|l|l|l|l|}
\hline \multicolumn{2}{|c|}{} & \multicolumn{2}{|l|}{ HPR } \\
\cline { 3 - 8 } \multicolumn{2}{|c|}{} & \multicolumn{2}{|l|}{ Acute Appendicitis } & $\begin{array}{l}\text { Appendicular } \\
\text { Perforation }\end{array}$ & \multicolumn{2}{l|}{ Recurrent Appendicitis } \\
\cline { 3 - 8 } & Count & $\%$ & Count & $\%$ & Count & $\%$ \\
\hline \multirow{2}{*}{$\begin{array}{l}\text { Hyperbilirubinemi } \\
\text { a }\end{array}$} & Present & 57 & $69.5 \%$ & 11 & $100.0 \%$ & 2 & $28.6 \%$ \\
\cline { 2 - 8 } & Absent & 25 & $30.5 \%$ & 0 & $0.0 \%$ & 5 & $71.4 \%$ \\
\hline
\end{tabular}

$\mathrm{X}^{2}=10.44, \mathrm{df}=2, \mathrm{p}=0.005^{*}$

Out of 82 subjects who were diagnosed as acute appendicitis histopathologically $69.5 \%$ had Hyperbilirubinemia, out of 11 subjects who were histopathologically diagnosed as Appendicular Perforation 100\% had Hyperbilirubinemia and 20\% with recurrent appendicitis had Hyperbilirubinemia.

There was significant association between Hyperbilirubinemia and Histopathologically diagnosis.

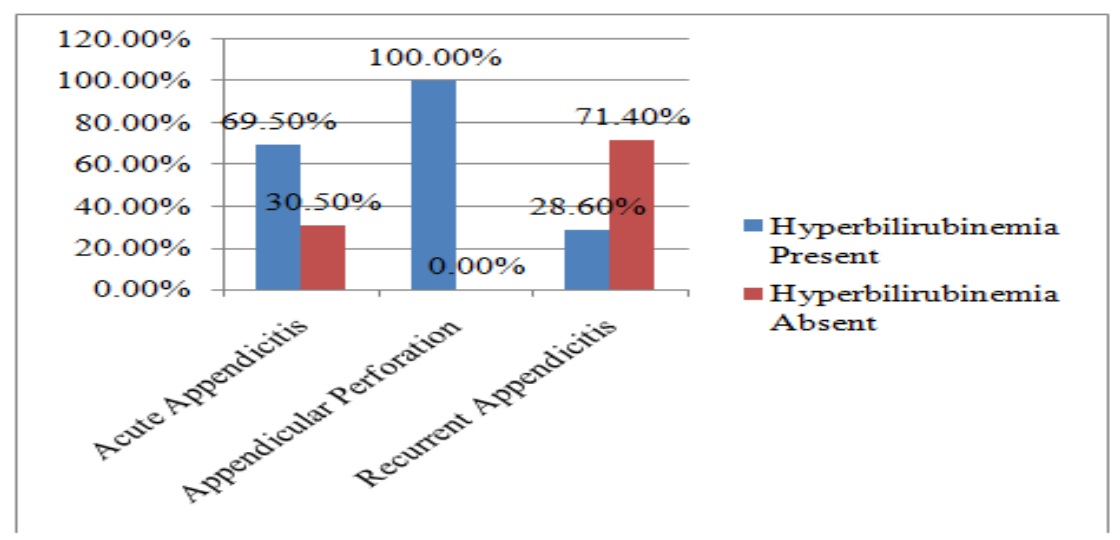

Figure 11: Bar diagram showing Association between Hyperbilirubinemia and clinical Histopathological diagnosis

Table 10: Validity of Hyperbilirubinemia in diagnosis if Acute appendicitis

\begin{tabular}{|l|l|l|l|l|l|}
\hline \multicolumn{2}{|c|}{} & \multicolumn{3}{|l|}{ HPR } & \multicolumn{2}{l|}{$\begin{array}{l}\text { Acute Appendicitis } \\
\text { Absent }\end{array}$} \\
\cline { 3 - 6 } \multicolumn{2}{|c|}{} & $\begin{array}{l}\text { Acute Appendicitis } \\
\text { Present }\end{array}$ & $\%$ & Count & $\%$ \\
\cline { 3 - 6 } & Count & $\% 9.5 \%$ & 13 & $72.2 \%$ \\
\hline \multirow{2}{*}{ Hyperbilirubinemia } & Present & 57 & $30.5 \%$ & 5 & $27.8 \%$ \\
\cline { 2 - 6 } & Absent & 25 & & \multicolumn{2}{l|}{} \\
\hline
\end{tabular}

\begin{tabular}{|l|l|}
\hline Parameter & Acute Appendicitis \\
\hline Sensitivity & $69.51 \%$ \\
\hline Specificity & $27.78 \%$ \\
\hline Positive Predictive Value & $81.43 \%$ \\
\hline Negative Predictive Value & $16.67 \%$ \\
\hline Diagnostic Accuracy & $62 \%$ \\
\hline
\end{tabular}

Hyperbilirubinemia had a diagnostic accuracy of $62 \%$ in diagnosis of acute appendicitis.

Figure12: Bar diagram showing Validity of Hyperbilirubinemia in Acute Appendicitis

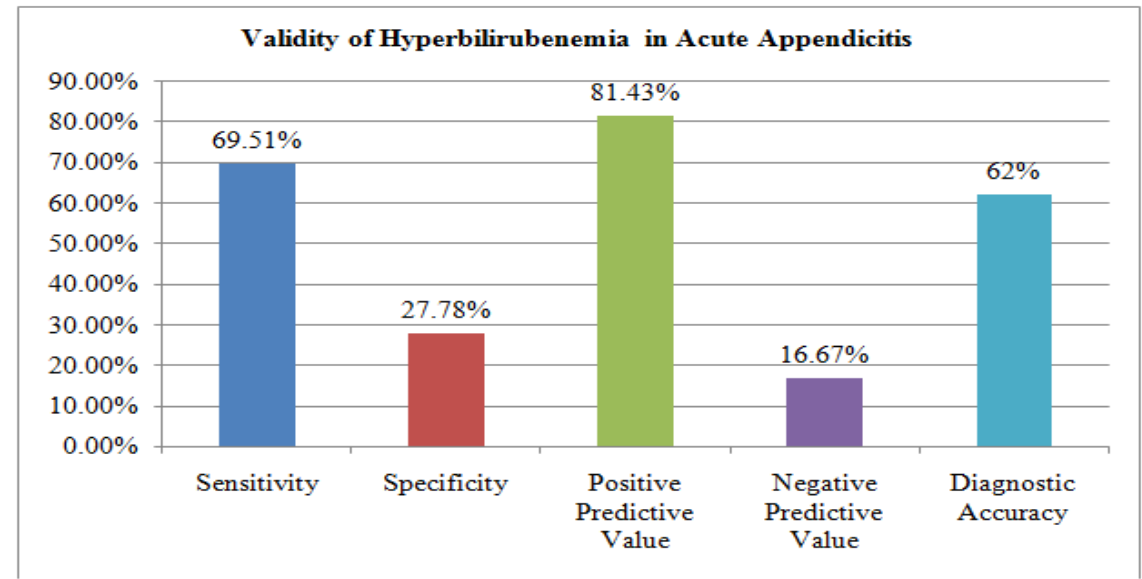


Table 11: Validity of Hyperbilirubinemia in diagnosis of Appendicular Perforation

\begin{tabular}{|l|l|l|l|l|l|}
\hline \multicolumn{2}{|c|}{} & \multicolumn{4}{|l|}{ HPR } \\
\cline { 3 - 6 } \multicolumn{2}{|c|}{} & AGA \& Appendicular & AGA \&Appendicular \\
Perforation Present & Perforation Absent \\
\cline { 3 - 6 } & Count & $\%$ & Count & $\%$ \\
\hline \multirow{2}{*}{ Hyperbilirubinemia } & Present & 11 & $100.0 \%$ & 59 & $66.3 \%$ \\
\cline { 2 - 6 } & Absent & 0 & $0.0 \%$ & 30 & $34.7 \%$ \\
\hline
\end{tabular}

\begin{tabular}{|l|l|}
\hline Parameter & Appendicular Perforation \\
\hline Sensitivity & $100 \%$ \\
\hline Specificity & $33.71 \%$ \\
\hline Positive Predictive Value & $15.71 \%$ \\
\hline Negative Predictive Value & $100 \%$ \\
\hline Diagnostic Accuracy & $41 \%$ \\
\hline
\end{tabular}

Hyperbilirubinemia had a diagnostic accuracy of $41 \%$ in diagnosis of appendicular perforation. Were as $100 \%$ sensitivity and Negative predictive value was observed.

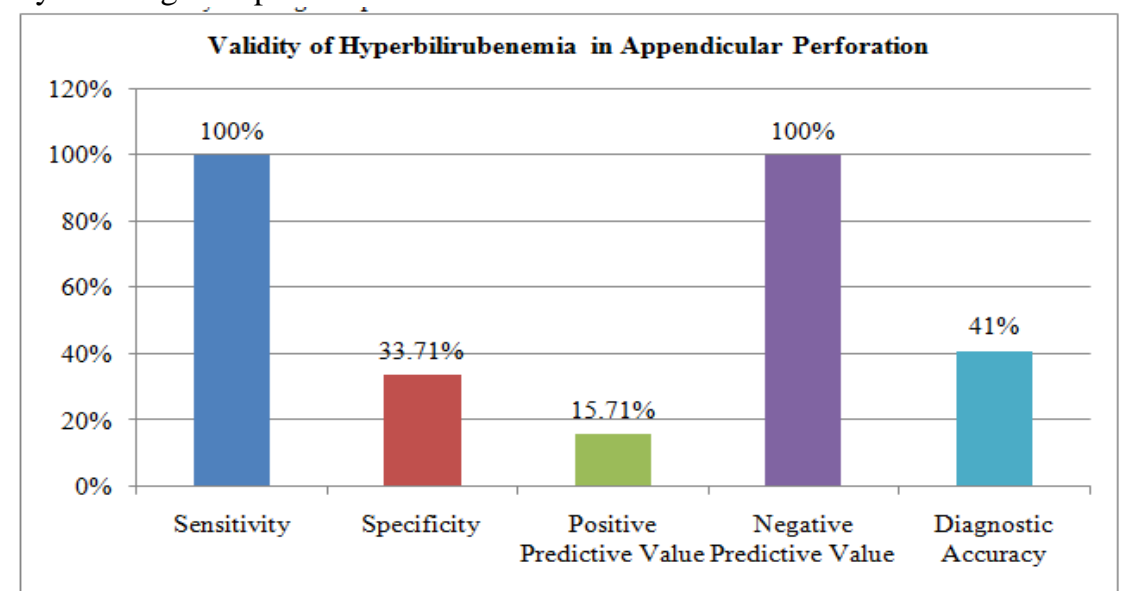

Figure 13: Bar diagram showing Validity of Hyperbilirubinemia in diagnosis of Appendicular Perforation

Table 12: Validity of Hyperbilirubinemia in diagnosis of Recurrent Appendicitis

\begin{tabular}{|l|l|l|l|l|l|}
\hline \multicolumn{2}{|c|}{ HPR } \\
\hline \multicolumn{2}{|c|}{$\begin{array}{l}\text { Recurrent Appendicitis } \\
\text { Present }\end{array}$} & Recurrent Appendicitis Absent \\
\cline { 3 - 7 } & Count & $\%$ & Count & $\%$ \\
\hline \multirow{2}{*}{ Hyperbilirubinemia } & Present & 2 & $28.6 \%$ & 68 & 73.11 \\
\cline { 2 - 6 } & Absent & 5 & $71.4 \%$ & 25 & 26.89 \\
\hline
\end{tabular}

\begin{tabular}{|l|l|}
\hline Parameter & Recurrent appendicitis \\
\hline Sensitivity & $28.57 \%$ \\
\hline Specificity & $26.88 \%$ \\
\hline Positive Predictive Value & $2.85 \%$ \\
\hline Negative Predictive Value & $83.33 \%$ \\
\hline Diagnostic Accuracy & $27 \%$ \\
\hline
\end{tabular}

Hyperbilirubinemia had a diagnostic accuracy of $27 \%$ in diagnosis of Recurrent appendicitis.

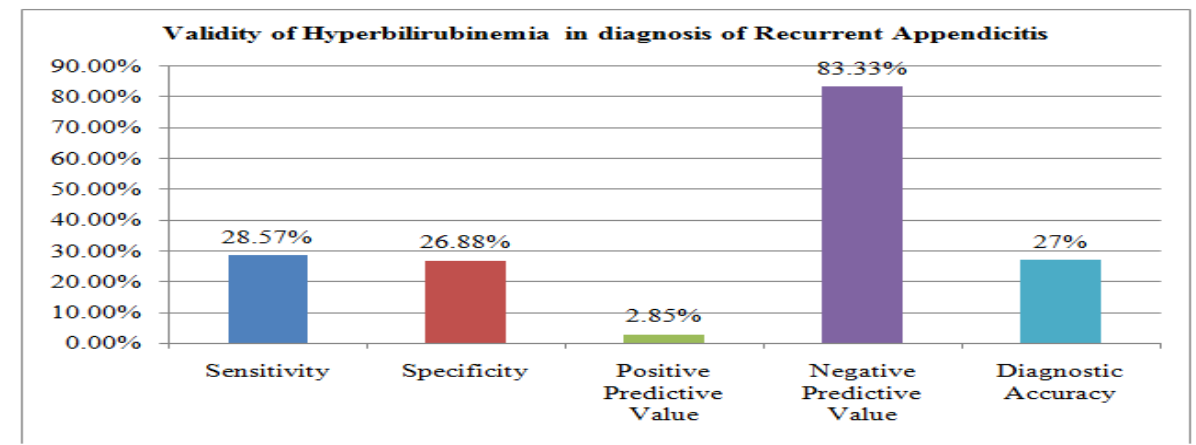

Figure 14: Bar diagram showing Validity of Hyperbilirubinemia in diagnosis of Recurrent Appendicitis 
Table 13: Area under the Curve for Diagnosis of Various types of Appendicitis

\begin{tabular}{|c|c|c|c|c|c|c|c|}
\hline \multicolumn{8}{|l|}{ Area Under the Curve } \\
\hline \multirow{3}{*}{ Diagnosis } & \multicolumn{7}{|c|}{ Test Result Variable(s): Total Bilirubin } \\
\hline & \multirow[t]{2}{*}{ Area } & \multirow[t]{2}{*}{ P value } & \multicolumn{2}{|c|}{$\begin{array}{l}95 \% \\
\text { Confidence Interval } \\
\end{array}$} & \multirow{2}{*}{$\begin{array}{l}\text { BilirubinCutoff } \\
\text { Value }\end{array}$} & \multirow{2}{*}{ Sensitivity } & \multirow{2}{*}{ Specificity } \\
\hline & & & Lower & Upper & & & \\
\hline Acute Appendicitis & 0.268 & $0.002 *$ & 0.108 & 0.428 & 1.150 & 0.671 & 0.222 \\
\hline Appendicular Perforation & 0.987 & $<0.001 *$ & 0.968 & 1.000 & 1.850 & 1.000 & 0.921 \\
\hline Recurrent Appendicitis & 0.294 & 0.070 & 0.152 & 0.436 & 1.250 & 0.286 & 0.344 \\
\hline
\end{tabular}

Area under the curve was highest for appendicular perforation with respect to Total Bilirubin levels. Total Bilirubin of 1.85 cut off had $100 \%$ sensitivity and $92 \%$ specificity in diagnosis of appendicular perforation.

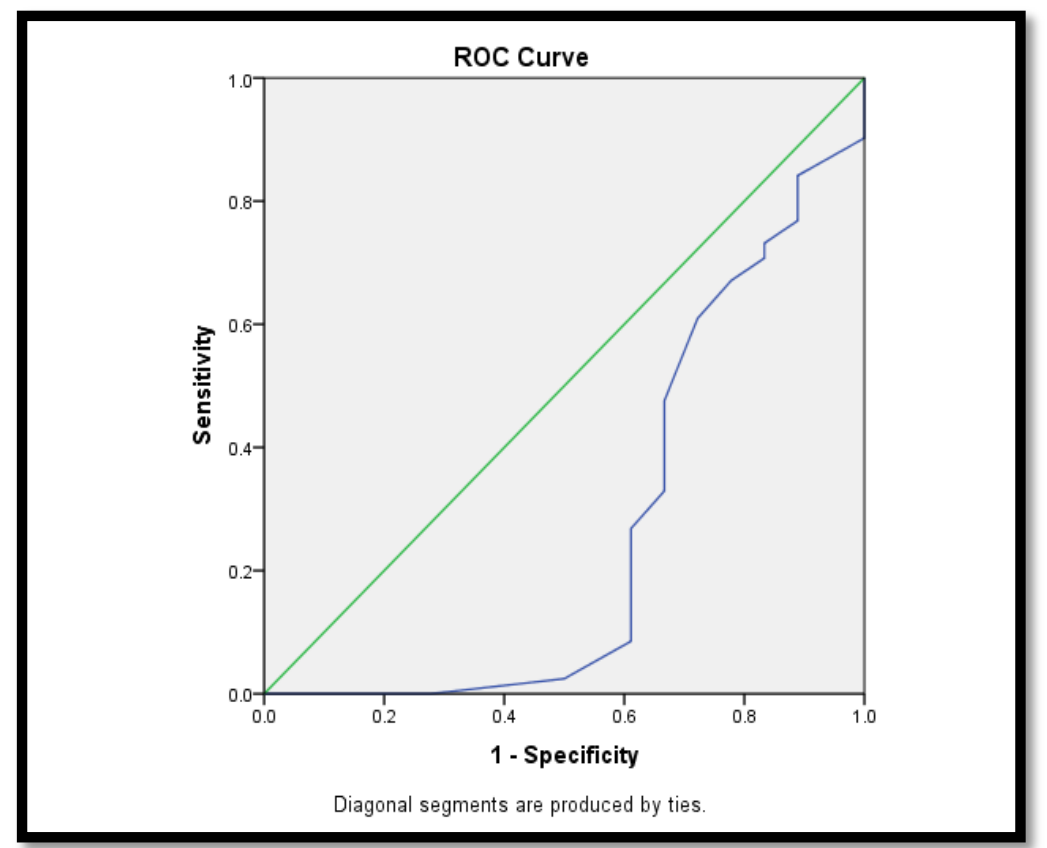

Figure 15: ROC curve showing Area under curve for Acute Appendicitis

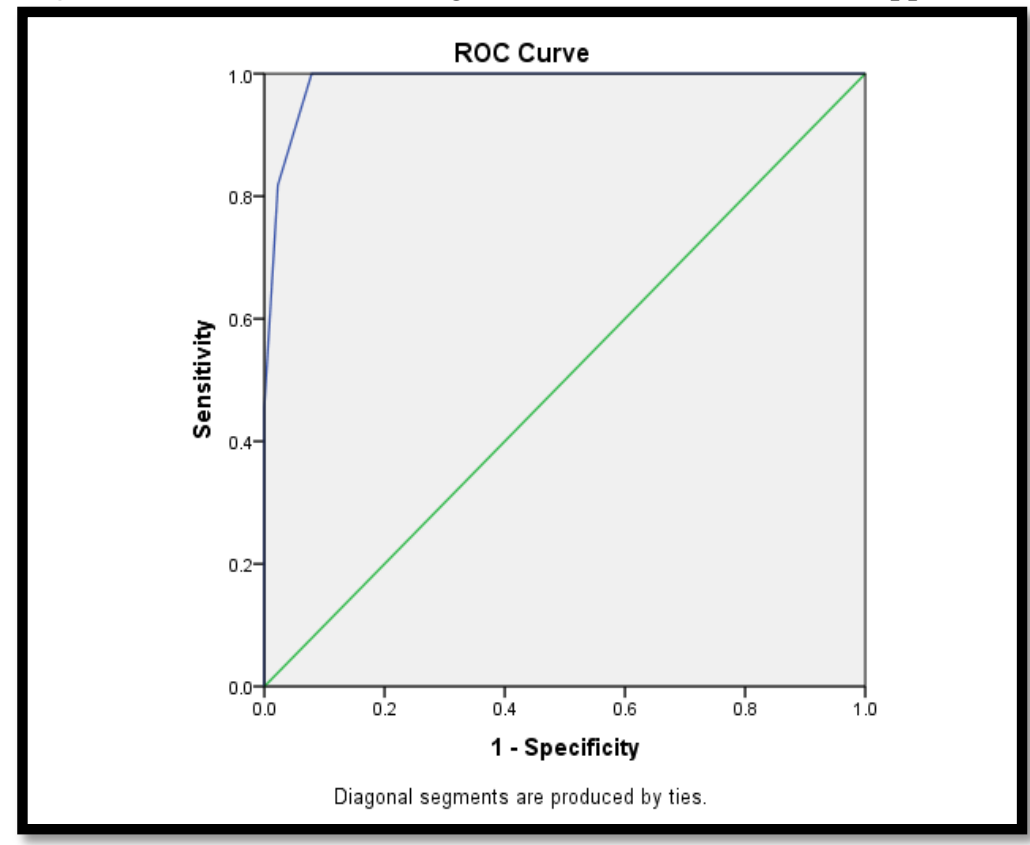

Figure 16: ROC curve showing Area under curve for Appendicular Perforation 


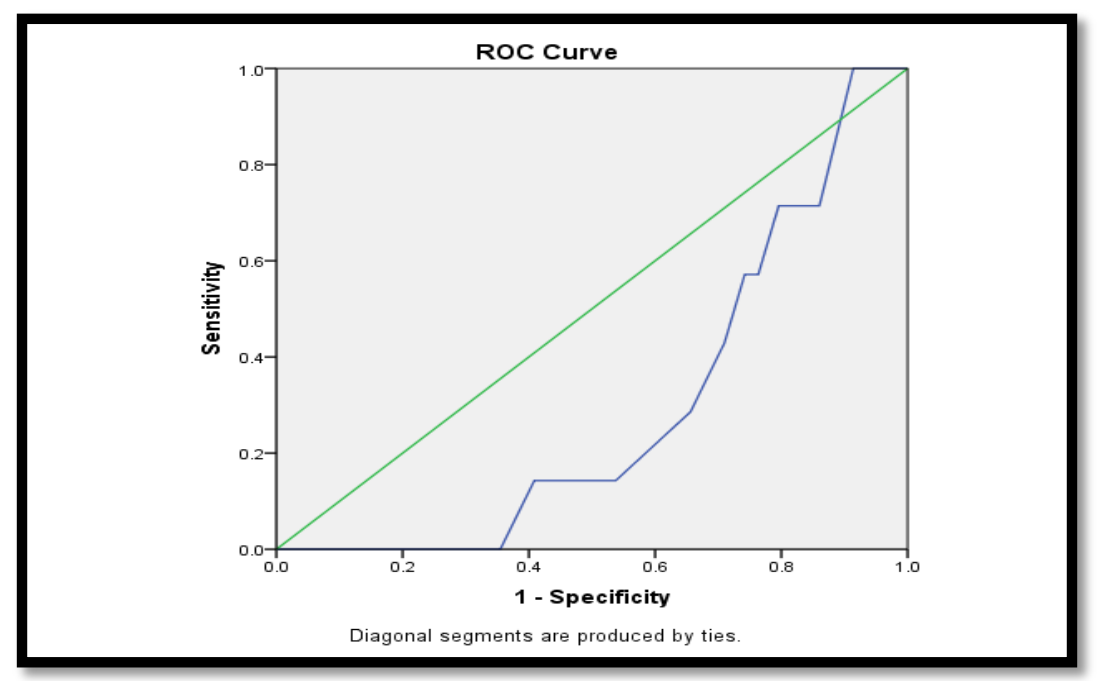

Figure 17: ROC curve showing Area under curve for Recurrent Appendicitis

\section{Discussion}

Acute appendicitis appears to be the most common cause for "Acute Surgical abdomen" ${ }^{1.2}$.Appendicectomy is the commonest emergency abdominal surgery, performed by a surgeon ${ }^{1}$. In Western countries About $8 \%$ of people will experience appendicitis in their lifetime. The incidence of acute appendicitis is maximum in the second and third decade. It is comparitively rare in infants, but becomes more common in childhood and early adult life. The incidence of appendicitis remains equal in both males and females before puberty. By the age of 25 , which includes the teenagers and the young adults, where the male female ratio increases to $3: 2$.The rate of appendicectomy is $12 \%$ for men and $25 \%$ for women, where around $7 \%$ of all people undergo appendectomy for acute appendicitis during their lifetime. The major cause of acute appendicitis is believed to be due to obstruction of the lumen and Faecoliths are the usual causes for obstruction, Less common causes include hypertrophy of lymphoid tissue, tumors, intestinal parasites. ${ }^{3,23 .}$ The bacteriology of a normal appendix is similar to normal colon. The major organism commonly seen are Escherichia Coli and Bacteroidsfragilis, in normal appendix, in acute appendicitis, and in perforated appendicitis. However a wide variety of both facultative and anaerobic bacteria may be associated. ${ }^{23}$

The diagnosis of acute appendicitis is mainly clinical; however, a decision to operate based solely on clinical suspicion can lead to the removal of a normal appendix in upto 15 to $50 \%$ of cases.The premise that it is better to remove a normal appendix than to delay diagnosis does not help in improving the condition of the patient, particularly in the elderly, as such procedures are associated with complications in $50 \%$ cases. ${ }^{1,5}$ Hence, the diagnosis of Appendicitis still remains a dilemma even after many advances in various laboratory and radiological investigations. Thus, a new tool to help in the diagnosis of acute appendicitis would be welcomed.Serum Bilirubin level elevation will help in the accurate diagnosis of acute appendicitis and more importantly help in foreseeing and preventing the impending complications of acute appendicitis. This study was taken up to assess - if it is possible to add serum bilirubin as a new laboratory marker to aid in the diagnosis of acute appendicitis and if so, does it have a chance to help us detect early an impending complication of acute appendicitis?

Importance of hyperbilirubinemia and its association in diagnosis of acute appendicitis has been postulated recently. ${ }^{54}$ There are very few case reports in the literature that describe the finding of hyperbilirubinemia in patients of acute appendicitis. An association between hyperbilirubinemia and diagnosis acute appendicitis and its complications has been hypothesized. Our study was considered to know the relationship between hyperbilirubinemia and acute appendicitis and to evaluate it as a diagnostic marker for acute appendicitis and also, to find if any correlation of elevated bilirubin levels have a predictive potential role in the early diagnosis of Appendicular perforation.Our study of the 100 patients enrolled for the study, 51 patients $(51 \%)$ were males while the remaining 49 patients $(49 \%)$ were females. The mean age in our study population (100 patients) was $25.41 \pm 11.14$ years. In our study $90 \%$ of subjects were below 40 years and $10 \%$ of them were above 40 years of age. This is consistent with the quoted incidence of Appendicitis in the literature where it is most commonly seen in patients in their second to fourth decades of life. Total Bilirubin was elevated in $63 \%$ of subjects, Direct Bilirubin levels were elevated in $24 \%$ and Hyperbilirubinemia was present in $70 \%$ of subjects based on elevated total Bilirubin or raised direct Bilirubin. Estrada et al had found hyperbilirubinemia in $59(38 \%)$ of 157 patients studied with acute appendicitis. The mean total serum bilirubin of all 100 patients was $1.3 \pm 0.6 \mathrm{mg} / \mathrm{dl}$, which was above the normal range $(\leq 1.2 \mathrm{mg} / \mathrm{dL})$ considered for the study, hence 
indicating the occurrence of hyperbilirubinemia. ${ }^{15}$ The mean of Direct bilirubin was $0.5 \pm 0.3 \mathrm{mg} / \mathrm{dl}$, Our finding was consistent with hyperbilirubinemia found in a study conducted by Khan S, who found average level of serum bilirubin in his study population to be $2.38 \mathrm{mg} / \mathrm{dL}$. The mean SGOT was $36.2 \pm 15.8$, SGPT was $32 \pm$ 12.7, ALP was $164.6 \pm 9$.

In our study clinically $87 \%$ were diagnosed to have acute appendicitis, $5 \%$ as appendicular perforation and $8 \%$ as recurrent appendicitis. Out of 87 patients who were clinically diagnosed as acute appendicitis $72 \%$ (63 patients) had Hyperbilirubinemia, out of 5 patients who were clinically diagnosed as Appendicular Perforation $100 \%$ had Hyperbilirubinemia and $25 \%$ (2 patients) with recurrent appendicitis had Hyperbilirubinemia. This suggest there was significant association between Hyperbilirubinemia and clinical diagnosis.Per operatively $86 \%$ were diagnosed as acute appendicitis, $11 \%$ as appendicular perforation and $3 \%$ as recurrent appendicitis. Out of 86 patients who were diagnosed as acute appendicitis per operatively $67.4 \%$ had Hyperbilirubinemia, out of 11 patients diagnosed as Appendicular Perforation were per operatively $100 \%$ had

Hyperbilirubinemia and $33.3 \%$ with recurrent appendicitis had Hyperbilirubinemia. There was significant association between Hyperbilirubinemia and per operative diagnosis. The diagnosis was confirmed post-operatively by histopathological reports (HPR).Based on histopathologicalreports , $82 \%$ were diagnosed as acute appendicitis, $11 \%$ as acute gangrenous appendicitis with perforation and $7 \%$ as recurrent appendicitis. Out of 82 patients were diagnosed as acute appendicitis histopathologically $69.5 \%$ had Hyperbilirubinemia, out of 11 patients were diagnosed as acute gangrenous appendicitis with Perforation histopathologically, $100 \%$ had Hyperbilirubinemia and $20 \%$ with recurrent appendicitis had Hyperbilirubinemia.

There was significant association between Hyperbilirubinemia and Histopathologically diagnosis. The total leukocyte count was found to be elevated in 52 patients $(52 \%)$ of the total 100 patients. The mean of TLC count in all patients was $10.8 \pm 4.2$. The mean bilirubin levels in patients diagnosed with Acute appendicitis was $1.2 \pm 0.5 \mathrm{mg} / \mathrm{dl}$, while in patients diagnosed with Appendicular perforation was $2.2 \pm 0.3 \mathrm{mg} / \mathrm{dL}$. Hence, we see that patients with Appendicular perforation had higher levels of bilirubin as compared to that of acute appendicitis. So we found that, patients with features suggestive of appendicitis with higher values of bilirubin, are more susceptible to Appendicular perforation than those with normal or slightly elevated total serum bilirubin.Sand et al in his study found the mean bilirubin levels in patients with Appendicular perforation to be The mean direct bilirubin level in patients with acute appendicitis was $0.4 \pm 0.3$ and appendicular perforation 0.9 \pm 0.4 . The value in appendicular perforation is twice as seen in acute appendicitis. Hence the elevated level of direct bilirubin has a higher prediction for appendicular perforation. The Sensitivity, Specificity, Positive predictive value, Negative predictive value and diagnostic accuracy was calculated from a $2 \times 2$ table. Sensitivity and Specificity of hyperbilirubinemia in predicting acute appendicitis was $69.51 \%$ and $27.78 \%$ respectively. Similarly Positive predictive value and Negative predicative value of bilirubin in predicting acute appendicitis was $81.43 \%$ and $16.67 \%$ respectively. Hyperbilirubinemia had a diagnostic accuracy of $62 \%$ in diagnosis of acute appendicitis. In appendicular perforation ,Hyperbilirubinemia had a diagnostic accuracy of $41 \%$ in diagnosis of appendicular perforation. Where as $100 \%$ sensitivity and Negative predictive value was observed.In recurrent appendicitis, Hyperbilirubinemia had a diagnostic accuracy of $27 \%$ in diagnosis of recurrent appendicitis .where as $29 \%$ sensitivity and $83 \%$ Negative predictive value was observed.The sensitivity in our study was more than that by Sand et al in which, he found the sensitivity and specificity in his study of hyperbilirubinemia for predicting Appendicular perforation to be $70 \%$ and $86.0 \%$ respectively. ${ }^{40}$ Hyperbilirubinemia was found in most of the patients diagnosed with acute appendicitis $(70 \%)$ or Appendicular perforation (100\%). Thus Hyperbilirubinemia had a diagnostic accuracy of $62 \%$ in diagnosis of acute appendicitis, $41 \%$ in appendicular perforation and $27 \%$ in diagnosis of recurrent appendicitissignificantly higher than those with a non-perforated appendicitis. ${ }^{40}$

\section{The present study suggests-}

\section{Conclusion}

- Serum bilirubin levels comes out to be a favorable laboratory marker for diagnosing acute appendicitis, however diagnosis of appendicitis remains static - clinical. Its level appears to be a useful marker in diagnosis of appendicitis and would be helpful investigation in managing acute cases.

- Patients with clinical signs and symptoms of appendicitis and with hyperbilirubinemia more than the normal range should be considered as having a higher chance of Appendicular perforation suggesting that serum bilirubin levels have a promising predictive potential for the diagnosis of Appendicular perforation.

\section{Bibliography}

[1]. O' Connel PR. "The Vermiform Appendix". In: Williams NS, BulstrodeCJK, O'Connell PR (Ed.). Bailey and Love's - Short practice of surgery. 25 ed. London:Arnold: 2008;p. 1204-8.

[2]. Smink DS, Soybel DI. "Appendix and Appendectomy”. In: Zinner MJ, Stanely W (eds) Maingot"s abdominal operations. $11^{\text {th }}$ ed. Ashely: McGraw Hill; 2007. p. 589-612. 
[3]. John Maa. "The Appendix". In Townsend CM, Beauchamp RD, EversBM, Mattox KL, eds. Sabiston Textbook of Surgery. 18 ${ }^{\text {th }}$ ed. Philadelphia, Pa: Saunders Elsevier; 2008. p: 1333-1347.

[4]. Deutsch A, Shani N, Reiss R. Are some appendectomies unnecessary: an analysis of 319 white appendices. J R CollSurgEdinb 1983; 28: 35-40.

[5]. Piper R, Kager E, Nasman P. Acute appendicitis a clinical study of 1018 cases of emergency appendicectomy. ActaChir Scand. $1982 ; 148: 51-62$.

[6]. Von vonTitte SN, McCabe CJ, Ottinger LW. Delayed appendicectomy for appendicitis causes and consequences. Am J Emerg Med. $1996 ; 14: 620$.

[7]. Temple CL, Huchcroft SA, Temple WJS. Natural History of appendicitis in adult: A prospectivestudy. Ann Surg. $1995 ; 221: 78$.

[8]. Grönroos JM, Grönroos P. A fertile-aged woman with right lowerabdominal pain but unelevated leukocyte count and C-reactive protein: acute appendicitis is very unlikely. Langenbecks Arch Surg 1999; 384: 437-40.

[9]. Jeffrey RB, Laing FC, Lewis FR. Acute appendicitis: high-resolution real-time US findings. Radiology 1987; 163: 11-4.

[10]. Puylaert JBCM, Rutgers PH, Lalisang RI, de Vries BC, van der WerfSD,Dörr JP, et al. A prospective study of ultrasonography in the diagnosis of appendicitis. N Engl J Med 1987; 317: 666-9.

[11]. Rioux M. Sonographic detection of the normal and abnormal appendix.AJR Am J Roentgenol 1992; 158: $773-8$.

[12]. Lim HK, Lee WJ, Lee SJ, Namgung S, Lim JH. Focal appendicitisconfined to the tip: diagnosis at US. Radiology 1996; 200: 799801 .

[13]. Alvarado A. A practical score for early diagnosis of acute appendicitis. Ann Emerg Med 1986; 15: 557-64.

[14]. Kalan M, Tabbot O, Cunlife WJ, Rich AJ. Evaluation of the modified Alvrado score in the diagnosis of acute appendicitis. A prospective study. Ann R Cool SurgEngl 1994; 76: 418-9.

[15]. Khan S. Evaluation of hyperbilirubinemia in acute inflammation of appendix: A prospective study of 45 cases. KUMJ 2006; 4(3) 15: $281-9$

[16]. Beg RB, Garlungton AW. Translocation of certain endogenous bacteria from the GI tract to mesenteric lymph node and other organ in Gonobiotic mouse model. Infect Immunol 1979; 23: 403-11.

[17]. Juric I, Primorac D, Zagar Z, Biocic M, Pavić S, Furlan D, et al. Frequency of portal and systemic bacteremia in acute appendicitis. PediatrInt 2001; 43(2): 152-6.

[18]. Koito Scathen WE, Desprez JD and Holden WD. A bacteriologic study in portal blood in man. Arch Surg 1995; 71: 404-9.

[19]. Wang P, Ayala A, Ba ZF, Zhou M, Perrin MM, Chaudry IH. Tumor necrosis factor -alpha produces hepatocellular dysfunction despite of normal cardiac output and hepatic microcirculation. Am J PhysiolGastrointet Liver Physiol 1993: 265(1): 126-32.

[20]. Wang P, Ba ZF, Chaudhary IH. Hepatic extraction of indo-cyanine green is depressed in early sepsis despite increase hepatic blood flow and cardiac output. Arch Surg 1991; 126(2):219-24.

[21]. Wang P, Chudhary IH. Mechanism of hepatocellular dysfunction during hyper dynamic sepsis. Am J PhysiolRegulIntegr Comp Physiol 1996; 270: 927-38 and 363-61.

[22]. Whiting JF, Green RM, Rosen AB, Gollan JL. TNF-alpha decreases hepatocyte bile salt uptake and mediated endotoxin-induced cholestasis. Hepatology. 1995; 22(4 Pt 1): 1273-8.

[23]. Bernard M. Jaffe and David H. Berger. "The Appendix". In Brunicardi F, Andersen D, Billiar T, Dunn D, Hunter J, Matthews J, et al. Schwartz's Principles of Surgery. $9^{\text {th }}$ ed. New York: McGraw Hill; 2009. p.1073-1092.

[24]. Inderbir Singh, GP Pal. Human embryology. Macmillan Publishers India Limited, Chennai. $6^{\text {th }}$ edition: $2007:$ p. 155

[25]. Jeremiah C Healy. "Vermiform appendix". Chapter 78. In Grays anatomy - The anatomical basis of clinical practice. $39^{\text {th }}$ edition. Churchill Livingstone. Susan Standring Elsevier: 2005; p. 1189-90.

[26]. Estrada JJ, Petrosyan M, Krumenacker J Jr, Huang S, Moh P. Hyperbilirubinemia in Appendicitis: A New Predicator of Perforation. Journal of Gastrointestinal Surgery 2007; 11: 714-5.

[27]. Berk PD, Wolkoff AW. Bilirubin Metabolism and Hyperbilirubinemia. In: Kasper DL, BraunwaldBraunwald E, Fauci AS, Hauser SL, Longo DL, Jameson JL, et al. Harrison"s Textbook of Internal Medicine. $16^{\text {th }}$ ed. Vol. II. New York: McGraw HillMedical Publishing Division; 2001. p. 919.

[28]. William C, Mayers, MD., Rocco Ricciardi, MD. Liver Function. In: Townsend CM, Beauchamp RD, Evers BM, Mattox KL, eds. SabistonText Book of Surgery. The biological basis of modern surgical practice, Book-I. 11 ${ }^{\text {th }}$ ed. A Heart Court Asia PTE LTD; 2001. p.1010.

[29]. Sherlock S, Dooley J. Assessment of Liver Function. In: Liver and hepatobiliary Diseases. $11^{\text {th }}$ Ed. Oxford: Black Well Publishing Company; 2002. p 20.

[30]. Kevin p. Lally, MD, Charles S. Cox Jr., MD, Richard J Andressy MD. Appendix. In: Townsend CM, Beauchamp RD, Evers BM, Mattox KL, eds. Sabiston Text Book of Surgery. The biological basis of modern surgical practice, Book-I. $11^{\text {th }}$ ed. A Heart Court Asia PTE LTD; 2001. p. 917.

[31]. Chand N, Sanyal AJ. Sepsis induced cholestasis. J Hepatol 2007; 45: 203-41.

[32]. Geier A, Fickert P, Trauner M. Mechanisms of disease: mechanismand clinical implications of cholestasis in sepsis. Nat ClinPractGastroenterolHepatol 2006; 3: 574-85.

[33]. Baron EJ, Bennion RS, Thompson JE, Strong C, Summanen P, McTeague M, et al. A microbial comparison between acute appendicitis and complicated appendicitis. Clin Infect Dis 1992; 14: 227-31.

[34]. Rink RD, Kaelin CR, Giammara B, Fry DE. Effects of live Escheria Coli and bacteroidsfragilis on metabolism and hepatic pO Circ Shock 1981; 8: 601-11.

[35]. Green RM, Beier D, Gollan JL. Regulation of hepatocyte bile salt transporters by endotoxin and inflammatory cytokines in rodents. Gastroenterology 1976; 111: 193-8

[36]. Utili R, Abernathy CO, Zimmerman HJ. Cholestatic effects of Escheria Coli endotoxin on isolated perfused rat liver. Gastroenterology 1976; 70: 248-53.

[37]. Shander A. Anemia in critically ill. Crit Care Clin 2004; 20: 159-78.

[38]. Agrez MV, House AK, Quinlan MF. Jaundice may herald an appendiceal abscess. Aust N Z J Surg 1986; 56 : 511-3.

[39]. Seller RA. Jaundice in acute appendicitis. Lancet 1969; 1: 838.

[40]. Sand M, Bechara GF, Holland-Letz T, Sand D, Mehnert G, Mann B. Diagnostic value of Hyperbilirubinemia as a predictive factor for Appendiceal perforation in Acute Appendicitis. Am J Surg 2009 Aug;198(2):193-8. 